\title{
Model of Communication Policy on the Development of the City without Slum (KOTAKU) Medan City
}

\author{
Yusnadi $^{1}$, Lahmuddin Lubis ${ }^{2}$, Cut Alma Nuraflah ${ }^{3}$ \\ ${ }^{1}$ Lecturer at State University of Medan, Indonesia \\ ${ }^{2}$ Lecturer at Islamic University of North Sumatra, Indonesia \\ ${ }^{3}$ Lecturer at Dharmawangsa University of Medan, Indonesia \\ alma294@yahoo.com
}

\begin{abstract}
The purpose of this study is to describe the model of communication policy on the development of the city without slum (Kotaku). The method which is used in this study was descriptive qualitative approach. This study is located in Medan Area sub district and Medan Helvetia sub district, Medan city. The informants were six people, consisting of three Kotaku facilitators, two leader of the Community Self-Help Agency (BKM) and one person from the Government (Dinas PUPR). Techniques of collecting data through the interview process using (semi-structured) interview guides, observation and document tracking. Techniques of analyzing data is used by Miles \& Huberman model, starting with data reduction, data display and conclusion drawing/verification. Check the validity of the data by using triangulation. The results shows that the model of communication policy on the development of the city without slum (Kotaku) Medan City uses a linear communication model where all policies related to planning the communication policy on the development of the city without slum (Kotaku) Medan city are carried out by the Government based on three things: the 1945 Constitution, Presidential Decree and Mayor's Decree.
\end{abstract}

Keywords : Model of communication policy; communication development; Kotaku Medan City

\section{Introduction}

Medan is known as the third largest city, after Jakarta and Surabaya. In terms of the rapid progress of business, Medan can be said to be able to compete with other major cities, this can be seen from the rampant development of shopping facilities, shopping units as the business center of Medan city and the construction of various housing complexes. But we often see at some points in the city of Medan far from regularity, both roads and residential buildings. The garbage is scattered, the drainage is black and full of dirt, damaged and improper roads, making the portrait of Medan city not as grand as the construction of the city of Medan itself. Apparently a lot of space and slums on the other side of the city of Medan.

Settlements and slum housing can cause various impacts, especially social impacts, where some people who are in slum environments are people with middle to lower economic capacity. The direct impact of the existence of slums is a decrease in the quality of the physical and social environment which results in lower environmental quality as a place to live. In addition, deviant behavior that is often found in slums in the form of non-disciplinary actions such as dumping garbage and dirt in any place (in drainage) and lack of public awareness of the environment is a fundamental problem in the midst of slum communities. The problem that occurs due to this behavior is that the face of the city becomes worse and dirty, floods, infectious diseases and so on.

Tirmidhi's Hadith which reads: "Verily Allah Ta'ala is kind and loves kindness, clean and loves cleanliness, noble and loves glory, is generous and loves generosity. Then clean your 
home page and do not resemble a Jew. (HR. Tirmidzi). ${ }^{1}$ This hadith shows that cleanliness is something that Allah loves. Therefore maintaining cleanliness (including the environment) is evidence or the fruit of the faith of a Muslim, because he has believed and believes that Allah SWT. is the substance of the Most Clean. Of course, this slum settlement is a problem that is not easy to overcome, due to a lack of awareness from the community, the weak role of the community, ignorance of the community or the behavior of the community itself. Therefore there must be an effort to strengthen the role of the community in structuring the current and future slum areas through a participatory city-based slum development program with assistance from facilitators.

For the issue of residential housing, the city of Medan has around 145 slum dwellings with 88,166 slum houses from more than 503,000 houses in the city of Medan. ${ }^{2}$ Problems that occur due to the existence of slums, including the face of the city to be deteriorating and dirty, floods, infectious diseases and so forth. In general, the problems that often occur in slum areas are the very narrow size of the building, not meeting the standards for habitable buildings, houses that coincide with each other making residential areas prone to fire hazards, narrow and inadequate road facilities, unavailability of networks drainage, lack of clean water supply, chaotic electricity network, inadequate MCK facilities. The regularity of buildings / buildings, drinking water supply, drainage, environment, waste water management, solid waste management, fire security, roads, green open space environment are some of the criteria that get slum handling.

In 2006, the government had begun to deal with community issues seriously. The national program for independent community empowerment (PNPM Mandiri) for example is one of the programs launched by the government with the aim of overcoming the problems of the people's economy through a revolving fund assistance program for the community. After the PNPM Mandiri program was considered able to be run independently by the community, the government stopped PNPM Mandiri and replaced the focus of the program with others, namely the prevention and improvement of the quality of urban slums (RP2KPKP) plans. In 2017 this RP2KPKP program through the Ministry of Public Works and Public Housing (PUPR), changed its name to a city program without slums (Kotaku).

Changing the name of the program is based on policies taken by the government. Where when President Susilo Bambang Yudhoyono (SBY) was replaced by President Joko Widodo (Jokowi) the policy direction changed. The President then issued a Presidential Regulation related to new program policies, namely the City without slums (Kotaku). The policy also includes the communication policies contained in the program.

The policy of communication according to Sean $\mathrm{McBraid}^{3}$ is related to principles, rules or guidelines where communication systems are built so that they become a framework that can be used to coordinate activities, choose approaches by looking at possible allocation of funds, structural decisions that influence communication activities and try set aside imbalances of external and internal factors and set priorities to be taken. Whereas Ely D. Gomez revealed that communication policy is a long-term strategic planning that must be elaborated in

\footnotetext{
${ }^{1}$ Imam As-Suyuthi, Al-Jami’ Ash-Shaghir, ; Muhammad Faiz Almath, 1100 Hadits Terpilih, sixth print (Jakarta : GIP. 1993), p. 311

${ }^{2}$ www. larispa.or.id, Accessed on 17 April 2016

${ }^{3}$ Cangara, Perencanaan dan Strategi Komunikasi, (Jakarta: Rajagrafindo Persada, 2013) p. 12
} 
operational planning, while communication strategies are tips or tactics carried out in carrying out communication planning. ${ }^{4}$

Communication in the context of development not only conveys the message, but also contains a transactional process where people who communicate with other parties try to form a meaning and develop their hopes. ${ }^{5}$ Communication is more than just conveying meaning, more than that, communication must be understood. ${ }^{6}$

Related to the policy model, Dunn revealed that a policy model is a mental building based on conceptualization and specification of elements of problem conditions, the model is also an artificial reconstruction of reality in a problem, stretching from energy and environment to the problem of poverty, welfare and various crimes. ${ }^{7}$

It is interesting to study that communication policies are often associated with political systems in a country ${ }^{8}$ so that if the political and economic structure can change then it also influences changes in communication policies, on the contrary in the unavailability of communication policies from certain political influences, especially the government system in power. So, in the formulation of communication policy formulations there are several issues of concern, including:

1. Formulate communication policies to achieve national goals in a broad framework,

2. Formulate communication policies to deal with information distribution, economics and other opportunities,

3. Formulate communication policies to solve problems of ethnic and cultural diversity,

4. Formulation of communication policies to provide protection against individual freedom.

The research method uses a qualitative descriptive approach. Located in Medan Sunggal District, Medan Area District and Medan Helvetia District, Medan City. The informants numbered six people, consisting of three Kotaku facilitators, two people from the BKM (Community Self-Sufficiency Agency) and one person from the government. Data collection techniques through the interview process using (semi-structured) interview guides, observation and document tracking. The data analysis technique uses the Miles \& Huberman model. Check the validity of the data using triangulation.

\subsection{Medan City Development Policy}

\section{Review of Literature}

Medan city development policy is inseparable from the regional long-term development plan (RPJPD) of Medan City, where the RPJPD is the direction of development and development of Medan City for 20 years, starting from 2006 to 2025. Based on RPJPD, Medan City will go through a level of progress, welfare, and community religiosity that want to be realized in stages and sustainably based on the carrying capacity and capacity of the city (environmentally sound). This is in accordance with the vision of the City of Medan, namely: "A City of Medan that is Advanced, Prosperous, Religious and Environmentally Friendly". In realizing the vision of Medan City as an Advanced, Prosperous, Religious and Environmentally

\footnotetext{
${ }^{4}$ Ibid, p. 62-63.

${ }^{5}$ Ruslan Rosady, Manajemen Humas dan Komunikasi: Konsepsi dan Aplikasi (Jakarta: PT Raja Grafindo Persada, 2002), p. 92

${ }^{6}$ Stephen P. Robbin, Prinsip-prinsip Perilaku Komunikasi Organisasi (Jakarta: Erlangga, 2002), p. 145.

${ }^{7}$ Ismail Nawawi, Manajemen Perubahan: Teori dan Aplikasi pada Organisasi Publik dan Bisnis (Bogor: Ghalia Indonesia, 2014), p.19

${ }^{8}$ Ibid, p. 18
} 
Friendly City, an effective step is needed in the form of a city development mission to become a reference for the direction of development.

The development mission of Medan City is as follows:

1. Realizing a strong and dynamic city economy.

2. Realizing a city society with knowledge and mastering technology, having faith and devotion and being independent.

3. Realizing urban infrastructure and facilities that are modern, reliable and environmentally sound.

4. Creating a city that is safe, comfortable and religious through equitable city development.

Medan city RPJPD is specified as a medium-term regional development plan (RPJMD)

in Medan, where the RPJMD is the direction of development and development of Medan City for 5 years. The RPJMD is also a translation of the Medan City RPJPD. Based on the RPJMD, the construction of Medan City in the period of 2016-2021 was directed towards the City reaching Medan "Becoming a Multicultural Future City, Competitive, Humanistic, Prosperous and Religious".

The development plans are contained in the Medan city spatial plan (Spatial Plan and Housing and Settlement Development and Development Plan -RP3KP) which has formulated the Medan spatial planning objectives for the 2011-2031 period, namely:

1. Realizing a safe, comfortable, productive and sustainable space and competitiveness and attractiveness as an investment destination;

2. Utilizing land, sea and air space for economic-based urban development activities in the trade and services sector, environmentally friendly tourism and industry.

More concretely, the government poured in a development plan and development of housing and residential areas (Rp. 3KP) which began in $2015 \mathrm{~S} / \mathrm{D} 2019$, which is referred to as the preparation stage. The preparation stage is the process of maturing plans as regional regulations, socialization, and implementation of plans that are urgent and possible to carry out development. Stage Year 2, 2020 up to 2024 is the stage of implementation of prioritized development plans and continued strategic development. Whereas Phase 3, Year 2025 until 2029 , is an advanced stage of the previous development stage, especially the development of infrastructure and supporting advice, and stage 4, Year 2030 to 2034. It is an advanced stage of the previous development stage, especially the development of infrastructure and facilities support. All urban settlement and infrastructure development strategies (SPPIP) are development strategies developed to synchronize development plans with spatial plans related to residential areas and urban infrastructure. So that a comprehensive strategy is obtained to plan and solve all problems related to residential areas and urban infrastructure. The Medan City Settlement and Infrastructure Development Strategy (SPPIP) prepared in 2010 has formulated the vision of the City of Medan Settlement and Infrastructure Development, namely: "Realization of quality and sustainable settlements and infrastructure in 2030".

\subsection{Development of Kotaku (city without slums)}

All development policies of Medan city will not be realized if concrete development programs are not carried out. So related to the issue of infrastructure that answers the problems of housing and slums in the Medan city, the local government together with the central government nationally plans a development program called city development without slums (Kotaku). A city without slums (Kotaku) is expected to be a collaboration platform that supports the handling of 38,431 Ha of slum areas that are carried out in stages throughout Indonesia through capacity building of local governments and communities, institutional 
strengthening, planning, improvement of infrastructure and basic services at the city and community level to support the achievement of the 2015-2019 RPJMN target, namely the eradication of urban slums to 0 percent.

Program of city without slums (Kotaku) is a development program that uses a development model with the aim of fulfilling basic needs, Kotaku focuses on service to the basic needs of the community. The role of the Government in this program as a service provider, with administrative planning that is measurable and makes the budget adequate as a program strength. Kotaku development policy is inseparable from the communication of Kotaku's development. Because development communication is the process of disseminating messages by a person or group of people to audiences in order to change attitudes, opinions, and behavior in order to increase physical progress and inner satisfaction, which in harmony is felt equally by all people. ${ }^{9}$ In a broad sense, development communication encompasses the role and function of communication (as activity of exchanging messages in a timeless manner) among all parties involved in the development effort; especially between the community and the government, since the planning process, then implementation, and assessment of development. Whereas in a narrow sense, development communication is all efforts and means, as well as techniques for delivering ideas, and development skills that come from those who initiated development and are appointed to the wider community. ${ }^{10}$ So that communication and development are two things that cannot be separated.

\subsection{Kotaku Development Policy}

Policy is the initial planning of the development strategy. Starting a program with policy can provide a basic framework before planning and strategy are implemented, on the contrary a plan will operationalize the policies that have been set up to achieve a goal. The following interview with the Kotaku team gave a basic description of the city's development policies without slums:

The facilities and infrastructure of the house are indeed the necessity of life for many people, who are instructed by the Constitution, P $28 \mathrm{H}$ paragraph 1, that the community has the right, to access to their welfare, infrastructure that is proper for their lives, so it fulfills basic rights human. ${ }^{11}$

From the interviews, it was known that the facilities and infrastructure of the house were the necessities of life for the community, which was ordered by the Constitution, $\mathrm{P} 28 \mathrm{H}$ paragraph 1, that the community had the right, access to welfare, adequate infrastructure for life. The following are community statements regarding the policies underlying the Kotaku program:

Kotaku program that I know is in accordance with the government program, which means that this city program without slums is how to create beautiful, cool, safe and neat conditions. Kotaku program leads to development that is close to feasibility. A decent environment, decent settlement, that's the priority of Kotaku program. In accordance with our legal basis Article 33 of the 1945 Constitution, it is stated that the government guarantees the feasibility of human life. Then another legal basis arises which is included in government regulations, regulations and so forth. That's the foundation of Kotaku program. ${ }^{12}$

\footnotetext{
9 Onong Uchjana Effendy. Ilmu Komunikasi Teori dan Praktek (Bandung: Remaja Rosdakarya), p. 92.

${ }^{10}$ Zulkarnen Nasution, Komunikasi Pembangunan: Pengenalan Teori dan Penerapannya, (Jakarta: Raja Grafika Persada, 1996), p. 106.

${ }^{11}$ Interview with Yeni Siregar, Team of Kotaku, February 19, 2019

12 Interview with Maskud Dahnial, Tegal Sari BKM, February 24, 2019
} 
In addition, Maskud also stated, constitutionally, the Kotaku program is a realization of the Constitution that guarantees decent livelihoods for all Indonesian people. ${ }^{13}$ The main foundation of the Constitution relating to Housing and Settlement Areas that is not suitable for habitation is Constitution No. 1 of 2011. From several references related to government policies originating from the 1945 Constitution, there are several Articles in the Constitution which form the basis for handling slums is as follows:

a. Article 5. Paragraph (1) The state is responsible for the implementation of housing and residential areas whose development is carried out by the government; Paragraph (2) Coaching is carried out by: (a) Ministers at the national level; (b) Governors at the provincial level and (c) Regents / Mayors at the Regency / City level.

b. Article $28 \mathrm{H}$. Paragraph (1). Everyone has the right to live in physical and spiritual prosperity, to live, and to get a good and healthy environment. Article 94. Paragraph (3) Prevention and improvement of the quality of slum housing and slum settlements must be carried out by the government, regional government, and / or everyone.

c. Article 95. Paragraph (1-4) Prevention of the growth and development of slums and slum settlements is only implemented through (a) supervision \& control (b) community empowerment.

d. Article 103. Paragraph (1-3) Management to maintain and maintain the quality of housing and settlements on an ongoing basis is carried out by the community independently and can be facilitated by the regional government.

e. Article $28 \mathrm{H}$ of the Constitution of the Republic of Indonesia stipulates that every person has the right to live in prosperity physically and spiritually, has a place to live and get a good and healthy environment and has the right to receive health services.

f. Article 9. Paragraph (3) Constitution No. 30 of 1999 concerning Human Rights; everyone has the right to a good and healthy environment.

g. Article 44 of Constitution No. 32 of 2009 concerning protection and management of the environment: Every drafting of legislation at the national and regional levels must pay attention to the protection of environmental functions and the principle of protecting environmental functions and the principles of protection and management of environmental support in accordance with the provisions stipulated in this Act. .

h. Article 65. Paragraph (1) Constitution No. 32 of 2009 concerning Protection and Management of the Environment: Everyone has the right to a good and healthy environment as part of human rights. Paragraph (3): Everyone has the right to submit a proposal and / or objection to a business plan and / or activity which is expected to have an impact on the environment.

i. Article 66 of Constitution No. 32 of 2009 concerning Protection and Management of the Republic of Indonesia: Every person who fights for the good and healthy environment can be prosecuted in a criminal or civil suit.

\section{Research Methods}

The method which is used in this study was descriptive qualitative approach. This study is located in Medan Area sub district and Medan Helvetia sub district, Medan city. The informants were six people, consisting of three Kotaku facilitators, two leader of the

${ }^{13}$ Ibid. 
Community Self-Help Agency (BKM) and one person from the Government (Dinas PUPR). Techniques of collecting data through the interview process using (semi-structured) interview guides, observation and document tracking. Techniques of analyzing data is used by Miles \& Huberman model, starting with data reduction, data display and conclusion drawing/ verification. Check the validity of the data by using triangulation.

\section{Discussion}

Based on the constitution that related to the environment, settlements and the rights of citizens, the government establishes the handling of housing and slums as a national target as outlined in the 2015-2019 National Medium Term Development Plan (RPJMN). In the 20152019 RPJMN, it was stated that one of the targets for the development of residential areas was the achievement of the reduction of urban slum settlements to 0 (zero) hectares through the handling of 38,431 Ha of slum areas.

Based on the 2015-2019 RPJMN, all programs in the Directorate General of Human Settlements (DGHS) of the Ministry of Public Works and Public Housing (Ministry of Public Works) within the next 5 years will create habitable settlements until they reach 0 Ha slum without displacing. Therefore, the Directorate General of Cipta Karya of the Ministry of Public Works / PR initiated development with a collaborative platform to realize habitable settlements through the Kotaku Program. This program was strengthened by the Presidential Regulation No. 2 of 2015 concerning the development and development of urban areas through handling the quality of the residential environment, namely improving the quality of slum settlements, preventing the growth of new slums and sustainable livelihoods.

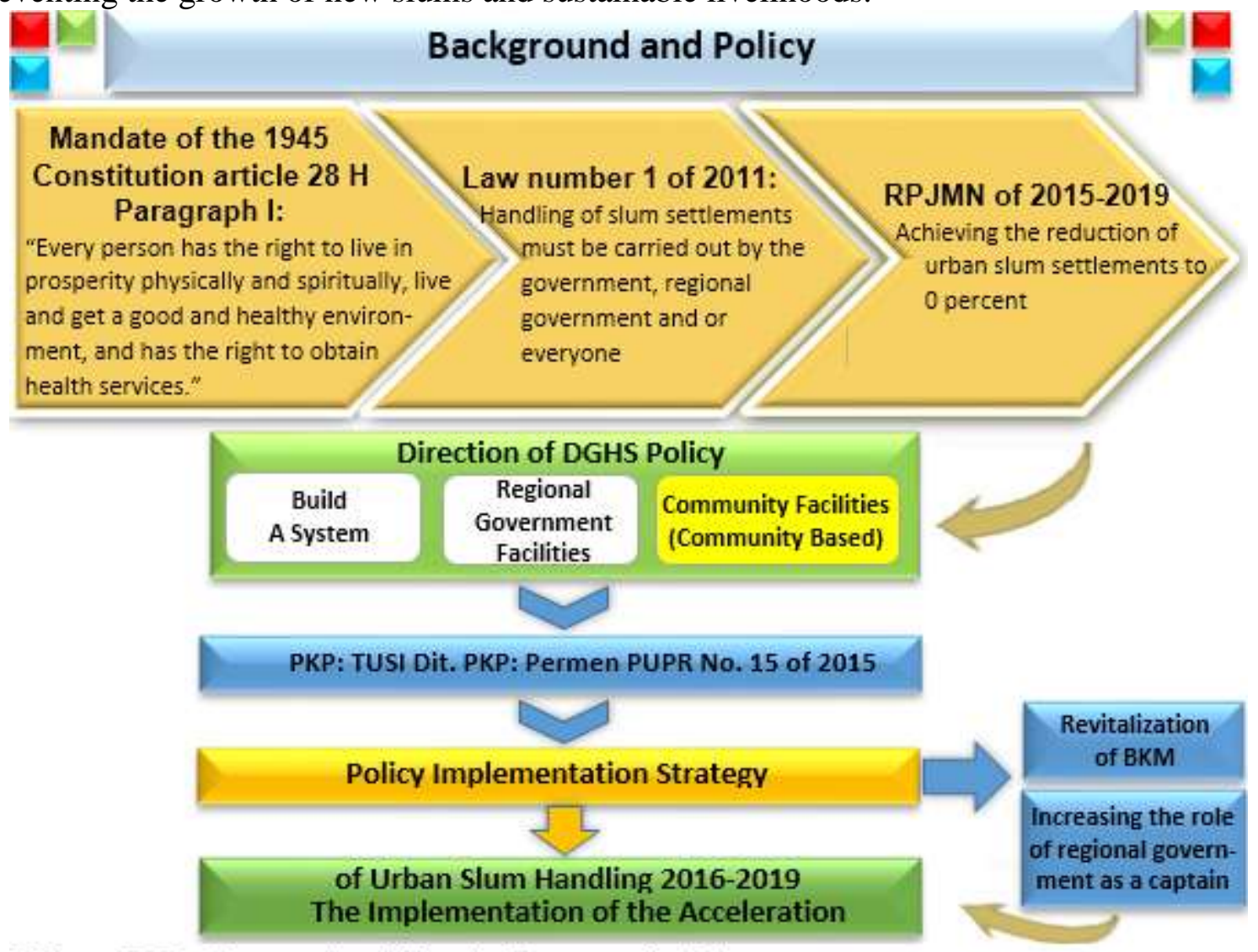

Figure 1. Background and Kotaku Program Policies 


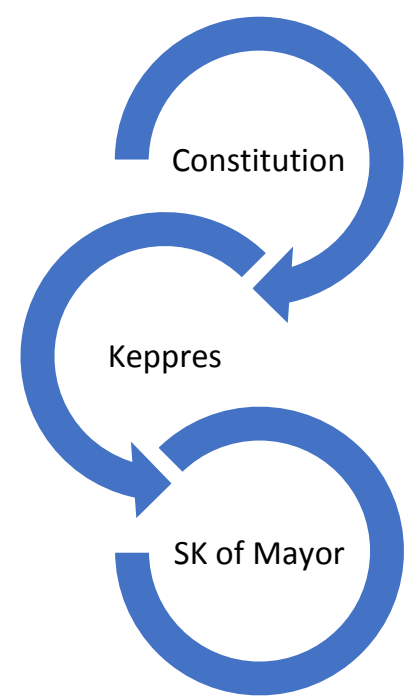

Figure 2. The Linear Communication Model in Kotaku Development Policy

The city program without slums (Kotaku) uses a development model that meets basic needs, focusing on service to the needs of the community. The role of the Government in this program as a service provider, with administrative planning that is measurable and makes the budget adequate as a program strength. In program policy, the communication model used is a linear (centralized) communication model. Program policies based on the Constitution as a legal umbrella, based on the Act, was born a Presidential Decree. Then the Mayor issued a Decree on the Determination of Slum and Slum Housing Locations as a basis for implementing the program. The government carries out planning in terms of policy, planning, and development strategies.

At the operational stage, the government handed over to the Kotaku team who carried out each of the strategies that had been set. The central government sets the facilitator team as a communicator, based on the Mayor's Decree, the facilitator analyzes the needs of the community and sets the target with the assistance of their assisted community. The community prepares the budget and schedule of activities and determines the work team, evaluates and so on, accompanied by the facilitator. While the government mobilized outside resources, planning messages using various communication channels to socialize the messages of the Kotaku program.

\section{Conclusion}

Although the construction of Kotaku was done through collaboration between the government, the Kotaku team (facilitator) and the community but still the policies carried out followed policies that had been determined both by the central government and local governments, but at least the Kotaku development had implemented communication planning principles, namely:

1. The participatory principle, with collaboration encourages participatory creation of all components, both from managers and stakeholders who are targeted by the plan.

2. The principle of sustainability. Planning a Kotaku development program that is made not only temporarily, but is continuously sustainable. Planning does not stop at one stage, but 
it must be continuous where each stake holder will do the next work after the previous work is completed.

3. The holistic, holistic principle, binds all units in one inseparable unit. Kotaku development planning does not run individually.

It can be concluded that Kotaku program policy, the communication model used is a linear (centralized) communication model where program policies are based on the Constitution as a legal umbrella, so the Presidential Decree was born. From the President's decision, the Mayor issued a Decree on the Determination of Slum and Slum Housing Locations as a basis for implementing the program, then after that the government planned the Kotaku program up to the Kotaku development strategy. After planning the strategy, the government handed over this program to be socialized to the community by the Kotaku facilitator team. But still, the government mobilizes outside resources, the government also plans messages using various communication channels to socialize the Kotaku program, which in general Kotaku uses various forms of media to disseminate policies and program implementation, both conventional media (TV, radio and newspapers) also online media.

\section{References}

As-Suyuthi, Imam., Al-Jami’ Ash-Shaghir, Muhammad Faiz Almath, 1100 Hadits Terpilih, six edition (Jakarta : GIP. 1993), p. 311

Cangara, Hafied, H. Perencanaan dan Strategi Komunikasi, Jakarta: Rajagrafindo Persada, 2013.

Effendy, Onong Uchjana Ilmu Komunikasi Teori dan Praktek (Bandung: Remaja Rosdakarya), p. 92 .

Nasution, Zulkarnen Komunikasi Pembangunan: Pengenalan Teori dan Penerapannya, (Jakarta: Raja Grafika Persada, 1996), p. 106.

Nawawi, Ismail Manajemen Perubahan: Teori dan Aplikasi pada Organisasi Publik dan Bisnis (Bogor: Ghalia Indonesia, 2014), p.19

Robbin, Stephen P. Prinsip-prinsip Perilaku Komunikasi Organisasi (Jakarta: Erlangga, 2002. Rosady, Ruslan Manajemen Humas dan Komunikasi: Konsepsi dan Aplikasi. Jakarta: PT Raja Grafindo Persada, 2002.

www. larispa.or.id, accessed on 17 April 2016 